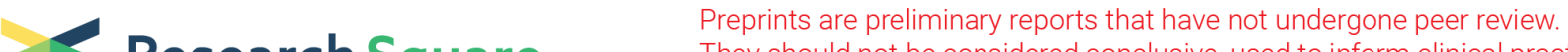 They should not be considered conclusive, used to inform clinical practice, or referenced by the media as validated information. \\ GDF-15 as a biomarker of aging
}

Huan Liu

Wuhan University Renmin Hospital

\section{Yun Huang}

Zhengzhou University Third Hospital and Henan Province Women and Children's Hospital

\section{Yongnan Lyu}

Wuhan University Renmin Hospital

\section{Wen Dai}

Wuhan University Renmin Hospital

\section{Yongqing Tong}

Wuhan University Renmin Hospital

\section{Yan Li ( $\sim$ liuh2015@whu.edu.cn )}

Renmin Hospital of Wuhan University https://orcid.org/0000-0002-7368-2204

\section{Original investigation}

Keywords: growth differentiation factor-15, aging, telomere length, telomerase activity, hTERT

Posted Date: June 4th, 2020

DOI: https://doi.org/10.21203/rs.3.rs-30717/v1

License: (c) (i) This work is licensed under a Creative Commons Attribution 4.0 International License. Read Full License 


\section{Abstract}

Background: The aging process is accompanied by the gradual development of chronic systemic inflammation (inflamm-aging). Growth differentiation factor-15 (GDF-15) is associated with inflammation and known to be a stress-induced factor. The present study aimed to explore the association of GDF-15 with aging.

Methods: In this cross-sectional study, serum GDF-15, hematological parameters, and biomedical parameters were determined in 120 healthy individuals (23-83 years old, males). Three telomere related parameters, including telomere length, telomerase activity, and the expression of human telomerase reverse transcriptase (hTERT) mRNA were also quantified.

Results: The older group has a higher levels of GDF-15 and lower expression of hTERT mRNA, and PBMC telomerase activity $(p<0.001)$. In individuals with high GDF-15 levels, they were older, and presented with the lower level of hTERT mRNA and T/S ratio $(p<0.01)$. Spearman correlation analysis shows that GDF-15 positively correlated with age $(r=0.664, p<0.001)$, and negatively correlated with telomere length $(r=-0.434, p<0.001)$, telomerase activity $(r=-0.231, p=0.012)$, and hTERT mRNA $(r=-0.206, p=0.024)$. Furthermore, in multivariate regression analysis, GDF-15 levels showed a statistically significant linear and negative relationship with PBMC telomerase activity ( $\beta$-coefficient $=-0.583,95 \% C /-1.044$ to $-0.122, p=0.014)$, telomere length $(\beta$-coefficient $=-0.200$, $95 \% \mathrm{Cl}-0.305$ to $-0.094, p<0.001)$, and hTERT mRNA ( $\beta$-coefficient $=-0.207,95 \% \mathrm{Cl}-0.312$ to $-0.102, p<0.001)$ after adjusting for confounders.

Conclusions: In conclusion, our results show that circulating GDF-15 is the potential biomarkers of aging that may influence the risk and progression of multiple aging conditions.

\section{Background}

The growth in human life expectancy in the last century was substantial, resulting in adults aged 65 years or older represent $8.5 \%$ of the world population, and it is expected that the number of individuals aged 80 or over will represent $17 \%$ of the world population by 2050 , which brings a great economic burden to the society [1]. Therefore, finding biomarkers of senescence that can be translated to the clinical setting are of particular interest.

Several aging biomarkers such as telomere length, telomerase activity, and the expression of human telomerase reverse transcriptase (hTERT) mRNA have been reported may influence the risk and progression of multiple aging conditions [2]. Uncontrolled telomere shortening may trigger immune senescence, chromosomal degradation, and cellular dysfunction, which have been related to the occurrence of age related diseases, including cardiovascular disease (CVD) and neurodegeneration [3]. Telomere length is believed to be a vitally important biomarker of aging, and many studies show that reductions in telomere length might be the independent risk factor for CVD $[4,5]$. Telomerase is important to maintain the relative stability of telomere length. It consists of TERT, the protein component of telomerase, and RNA component. The expression of hTERT mRNA and telomerase activity decreased with age [6]. Recently, growing evidence shows that TERT is protective in the microcirculation against prolonged vascular stress $[7,8]$. Among the different biomarkers proposed, including cell-free DNA and circulating extracellular RNAs $[9,10]$, growth differentiation factor (GDF-15) appears particularly promising due to the ease of collecting specimens and the low costs. However, little is known about how serum GDF-15 changes with age.

High levels of GDF-15 was first reported in 1997 in macrophages and acted as an autocrine regulatory molecule and belonged to the transforming growth factor $\beta$ (TGF- $\beta$ ) superfamily [11]. In the last two decades, GDF-15 has received 
lots of attention because of its multiple phenotypic functions, with roles in the regulation of obesity, cancer, nervous system disease, metabolism and CVD. Furthermore, serum GDF-15 levels are potential diagnostic markers for agingrelated diseases, such as cognitive impairment, frailty, and CVD [12-14].

Here, to gain a comprehensive assessment of the association between GDF-15 and aging. We measured GDF-15 levels, and three telomere related parameters, including telomere length, telomerase activity, and the expression of hTERT mRNA in individuals composed of 53 young (23 to 39 years old), 39 middle-aged (50-66 years old), 28 old (67-83 years old).

\section{Methods}

\section{Study population}

The research was approved by the Medical Ethics Review Committee of Renmin Hospital, Wuhan University, China. All the participants were asked to provide written informed consent in accordance with the Renmin Hospital of Wuhan University Ethics Committee. The study conforms to the principles outlined in the declaration of Helsinki.

We performed a cross-sectional study with a total of 120 individuals aged 23-83 years old were recruited from the physical examination center of Renmin Hospital of Wuhan University. Participants who are free of major chronic conditions and functional impairments are enrolled. In detail, 53 young (20-39 years old), 39 middle-aged (50-66 years old), 28 old (67-83 years old) individuals, and the age of the participants was defined by birth certificates stated at the time of recruitment [2]. Participants affected by infectious diseases, pulmonary edema, chronic renal function, or acute kidney injury, or those receiving thrombolysis treatment, or on immunosuppressive treatment were excluded from the study. Venipuncture was performed in the morning after the participants had fasted for at least 8 h.

\section{Laboratory methods}

Levels of the secretory form of human GDF-15 in crude serum samples were measured in duplicate using a commercial enzyme-linked immunosorbent assay (ELISA) kit (Quantikine, R\&D Systems, USA) with intra- and interassay coefficient of variation $<6 \%$ and $2.8 \%$, respectively. The assay detection range was $7.8-500 \mathrm{pg} / \mathrm{mL}$, and samples were diluted 10 times for detection.

Concentrations of total cholesterol (TC), triglycerides (TG), high-density lipoprotein cholesterol (HDL-c), low-density lipoprotein cholesterol (LDL-c), glucose, alanine aminotransferase (ALT), aspartate aminotransferase (AST), albumin (Alb), and blood urine nitrogen (BUN) were assayed using enzymatic methods with an ADVIA 2400 (Siemens, Germany). Counts of white blood cells (WBC), neutrophils (Neu), lymphocytes (LYM), monocytes (Mono), red blood cell (RBC), hemoglobin $(\mathrm{Hb})$ and peripheral blood mononuclear cells (PBMCs) were measured using the Sysmex XN20 system (Kobe, Japan).

\section{PBMCs isolation}

Peripheral blood mononuclear cells were isolated from peripheral blood by centrifugation with Ficoll-Paque Plus (GE Healthcare). PBMCs were used for the measurement of telomerase activity and telomere length. All cells were then stored at $-80^{\circ} \mathrm{C}$ until analysis

\section{Telomerase enzymatic activity assay}


Telomerase activity were assayed using a photometric ELISA based on the telomeric repeat amplification protocol (TRAP, Roche) as previously described [6]. Briefly, $2 \times 10^{5}$ PBMCs were isolated from each sample and stored at $-80^{\circ} \mathrm{C}$ pending analysis. Samples containing telomerase are added to the 3 'end of the biotinylated synthetic primer P1-TS, then P1-TS were used to amplify these products by PCR. The hybrid product was fixed to the microporous plate coated by biotin-labeled of streptomyces affinities primers, then peroxidase-linked digoxin antibodies were used to detect the PCR products. Finally, TMB is metabolized by peroxidase to form the colored products. Added stop reagent per well to stop color development and measured the absorbance within 30 min.

\section{PBMCs telomere length assay}

Total DNA was isolated from PBMCs using the MiniBEST Universal Genomic DNA Extraction Kit 5.0 (Takara) according to the manufacturer's instructions. DNA samples were measured for concentration and purity using the NanoDrop (Thermo Fisher Scientific). The quantitative PCR method was used to measure telomere length relative to standard reference DNA (T/S ratio), as described previously [15]. Primer sequences were as follows [6] and synthesized by Invitrogen: telg ACACTAAGGTTTGGGTTTGGGTTTGGGTTTGGGTTAGTGT, telc

TGTTAGGTATCCCTATCCCTATCCCTATCCCTATCCCTAACA; albu CGGCGGCGGGCGGCGCGGGCTGGGCGGAAATGCTGCACAGAATCCTTG, albd GCCCGGCCCGCCGCGCCCGTCCCGCCGGAAAAGCATGGTCGCCTGTT.

\section{Reverse transcriptase-quantitative PCR}

RNA was extracted by Trizol reagent (Takara) according to the manufacturer's instructions. RNA was quantified by Nanodrop SD-2000 spectrophotometer (PLCO) to measure the absorbance (A260 nm) and samples were then stored at $-80^{\circ} \mathrm{C}$ until use. The cDNA was reverse-transcribed using a PrimeScript ${ }^{\mathrm{TM}} \mathrm{RT}$ reagent kit with gDNA Eraser (Takara) in an ABI 9902 thermal cycler. The reactions were incubated in the thermal cycler for 2 min at $42^{\circ} \mathrm{C}, 15 \mathrm{~min}$ at $37^{\circ} \mathrm{C}$, and $5 \mathrm{sec}$ at $85^{\circ} \mathrm{C}$ and then held at $4^{\circ} \mathrm{C}$.

The cDNA was amplified by PCR using hTERT-specific primer and GAPDH primer pairs. PCR was performed for 40 cycles $95^{\circ} \mathrm{C} 30 \mathrm{~s}$ (each cycle consisting of $95^{\circ} \mathrm{C}$ for $30 \mathrm{~s}, 64^{\circ} \mathrm{C}$ for $90 \mathrm{~s}$, and $72^{\circ} \mathrm{C}$ for $30 \mathrm{~s}$ ). The PCR products were analyzed by electrophoresis on a $1 \%$ agarose. Primer sequences were as follows [6] and synthesized by Invitrogen: hTERT-For CGGAAGAGTGTCTGGAGCAA, Rev GGATGAAGCGGAGTCTGGA; GAPDH-For AGAAGGCTGGGGCTCATTTG, Rev AGGGGCCATCCACAGTCTTC.

\section{Statistical analysis}

Statistical analysis was performed using IBM SPSS software, version 20.0 (IBM, Armonl, NY, USA), GraphPad Prism 7.0 (GraphPad Software, La Jolla, CA, USA). Continuous variables were expressed as mean value \pm SD or median, percent 25-percent 75, according to normality of distribution. Differences among groups were analyzed by the oneway ANOVA for Gaussian distributed data and the Kruskal-Wallis $\mathrm{H}$ test where at least one column was not normally distributed. The correlation analysis was made by Spearman coefficient. The associations among GDF-15 with T/S ratio, leukocyte hTERT mRNA levels, and PBMC telomerase activity were performed by univariate and multivariable linear regression, respectively. And we transformed GDF-15 levels and leukocyte hTERT mRNA to the log10 scale for linear regression analysis. A two-sided $p$ value of $<0.05$ was considered statistically significant.

\section{Results}

\section{Baseline characteristics}


Demographic data for the cohort as related to chronological age are presented in Table 1. The difference in the red series is observed, presented in the lower level of hemoglobin and RBC in the older group $(p<0.01)$. Also significant differences are observed in the number of the platelets and lymphocytes, the older group has fewer platelets and lymphocytes $(p<0.05)$. And the levels of AST, TC, TG, TC/HDL-c, and glucose increased with age. On the contrary, levels of Alb decreased with age. Furthermore, the older group has a higher levels of GDF-15 and lower expression of hTERT mRNA, and PBMC telomerase activity. No significant differences in the distribution of the number of WBC, Neu, Mono, neutrophil to lymphocyte ratio, and levels of ALT, BUN, creatinine and LDL-C are observed.

Table 2 shows the baseline characteristics as stratified by GDF-15 tertiles. The medians of GDF-15 levels varied from $338.52 \mathrm{pg} / \mathrm{mL}$ in the bottom tertile up to $640.71 \mathrm{pg} / \mathrm{mL}$ in the top tertile. Patients with high GDF-15 levels are older, had higher number of blood monocytes, when compared to patients with low GDF-15 levels $(p<0.05)$. Kim et al, showed that the frailty and frailty criterion were significantly associated with lower erythrocyte levels of longchain n-3 PUFA[16]. Consistent with the previous study, in our study, the older group has less RBC. And the levels of AST and TC/HDL-c increased with GDF-15 levels. With regard to the numbers of WBC, Neu, LYM, neutrophil to lymphocyte ratio, platelets and levels of Hb, ALT, BUN, creatinine, TC, TG, HDL-C, LDL-C and glucose, no significant statistical difference is observed among different GDF-15 tertiles.

\section{Telomere-related parameters across different GDF-15 tertiles.}

Telomere length in PBMCs, relative levels of hTERT mRNA in leukocytes, and the activity of PBMC telomerase stratified by GDF-15 tertiles are presented in Table 3. Significant difference in the telomere-related parameters were observed, presented in the lower level of hTERT mRNA and T/S ratio in individuals with high GDF-15 levels ( $p<0.01)$. Moreover, the measurements of PBMC telomerase activity showed a consistent direction of effect over GDF-15 groups. Patients with high GDF-15 levels had a lower PBMC telomerase activity.

\section{Correlations among GDF-15 and various biomarkers.}

Fig. 1 shows the correlation among GDF-15 levels with various biomarkers. A statistically significant association between GDF-15 levels and hematological parameters is observed, presented in the negative correlation between GDF-15 and RBC ( $r=-0.303, p=0.003)$, and positive correlation between GDF-15 and Mono $(r=0.198, p=0.031)$. A statistically significant positive association was found with lipids, such as LDL-c and TC/HDL-c $(r=0.207, p=0.034$; $r=0.196, p=0.044$, respectively). Also, GDF-15 levels positively correlated with AST $(r=0.336, p<0.001)$, and negatively correlated with Alb $(r=-0.336, p=0.001)$.

\section{Correlations among age, T/S ratio, leukocyte hTERT mRNA levels, PBMC}

\section{telomerase activity and GDF-15.}

To further assess the correlation among age, T/S ratio, leukocyte hTERT mRNA levels, PBMC telomerase activity and GDF-15, the Spearman correlation method was performed. As shown in Fig. 2, GDF-15 levels are positively correlated with age $(r=0.664, p<0.001)$ (Fig. 2A), and negatively correlated with PBMC telomerase activity $(r=-0.231$, $p=0.012)$, telomere length $(r=-0.434, p<0.001)$, and WBC hTERT mRNA levels $(r=-0.206, p=0.024)$ (Fig. 2B, C and D).

\section{Univariate and multivariate linear regression}

To further explore the association of GDF-15 with T/S ratio, leukocyte hTERT mRNA levels, and PBMC telomerase activity, we performed multivariable linear regression, respectively. 
Table 4 displays the results of the univariate and multivariate regression analysis of PBMC telomerase activity and GDF-15. In the univariate linear regression analysis, PBMC telomerase activity positively associated with numbers of LYM, RBC, PLT, and levels of Alb, glucose, TC. In addition, PBMC telomerase activity negatively associated with GDF15 levels. In the multivariate linear regression analysis, PBMC telomerase activity showed a statistically significant linear and negative relationship with GDF-15 levels ( $\beta$-coefficient $=-0.583,95 \% C l-1.044$ to $-0.122, p=0.014)$ after adjusting for Neu, RBC, Alb and TC.

Table 5 shows that telomere length is negatively associated with GDF-15 levels ( $\beta$-coefficient $=-0.200,95 \% \mathrm{Cl}-0.305$ to $-0.094, p<0.001)$ after adjusting for glucose, TG, and HDL-C.

The association between hTERT mRNA and GDF-15 is also further evaluated by multivariate regression analysis. As summarized in Table 6, the expression of hTERT mRNA showed a statistically significant linear and negative relationship with GDF-15 levels ( $\beta$-coefficient $=-0.207,95 \% C /-0.312$ to $-0.102, p<0.001$ ) after adjusting for glucose.

\section{Discussion}

The current study explored the associations between serum GDF-15 and aging. Our result shows the older group has a higher levels of GDF-15, lower hTERT mRNA expression, and PBMC telomerase activity. The comparision of baseline characteristics among different GDF-15 tertiles shows a difference in the number of monocyte and erythrocyte, where the high GDF-15 group presents a lower number of monocyte and erythrocyte. These results coincide with those previously observed, metabolic alterations that occur in monocyte and erythrocyte during aging $[17,18]$. In individuals with high GDF-15 tertile, they displayed high levels of AST, and TC/HDL-c. This is in accordance with Tang et al, which demonstrates that blood lipid profiles have been ambiguously reported to be associated with aging-related disease. According to the Spearman correlation method, GDF-15 levels presented positively correlated with age, and negatively correlated with PBMC telomerase activity, telomere length, and WBC hTERT mRNA expression. Moreover, in the multivariate linear regression, statistically significant linear and negative relationship of GDF-15 with PBMC telomerase activity, telomere length, and hTERT mRNA expression were observed.

GDF-15 is stress-induced factor, the biological roles of GDF-15 are context-dependent and may vary with the stage of the disease [19-21]. In a systematic research, aimed to identify genes regulated in aging, and age-related diseases, GDF-15 is one of the high priority candidates [13]. In human endothelial cells, GDF-15 promotes radiationinduced senescence through the ROS-mediated p16 pathway, and contribute to the development of atherosclerosis [22]. GDF-15 levels are upregulated under the stress of ischemia-reperfusion, and it is important for the generation of reactive oxygen species and the development of senescence [23]. Furthermore, Talia et al. showed GDF-15 was associated with aging related impairment and changes, and predicted to be the potential biomarker of cognitive decline [24]. Consistent with previous studies, the olders displayed higher levels of GDF-15. And in high GDF-15 tertile group, individuals displayed high levels of AST, and TC/HDL-C. These biomedical parameters are correlated with aging-related disease, such as CVD.

The progression of aging is accompanied by the changes of hematological parameters. RBCs are the most abundant cell in our body, constitute approximately $83 \%$ of the total host cells [25]. During their 120-day lifespan, RBCs transport molecules of oxygen to all parts of the body [26]. When RBCs are used as the model to explore system metabolism in the context of cellular oxidant stress, presented that aged individuals are associated with a stressed erythropoiesis phenotype and contributed to the so-called "anemia in the elderly" [27]. Furthermore, aging promotes erythrocyte phagocytosis and contribute to the development of atherothrombosis [28]. Also, Pluta, et al demonstrated the effects of erythrocytes as the biomarker of Alzheimer's Disease [29]. Monocytes probably account 
for about $10 \%$ of all circulating leukocytes [30]. Monocytes play vital role in antigen presentation, tissue repair, inflammatory processes, and affect many age-related health situations, including atherosclerosis, and Alzheimer's disease [31, 32]. In patients with frailty, a higher number of monocytes is associated with frailty [33]. And monocytes present age-related changes [34,35]. In the current study, coincide with previous studies, our results showed the olders displayed lower number of erythrocytes. And in individuals with high GDF-15 tertile, they presented lower RBCs, and higher number of monocytes. According to the Spearman correlation method, GDF-15 levels showed negatively correlated with RBC, positively correlated with monocytes.

A meta-analysis of a case-control study revealed increased TC levels and decreased HDL-c levels are observed to be associated with an elevated risk of aging-related, such as Alzheimer's disease [36]. In germ-free mice, Albouery, et al proposed brain lipid composition changes with age, and microbiota alterations may be the regulator [37]. Our results are in line with these studies showing in individuals with high GDF-15 tertile, they displayed higher TC/HDL-C, and a statistically significant positive association was found between GDF-15 and TC/HDL-C.

Telomere length, and telomerase activity decline with age and are now considered to be the potential markers reflecting physical age that correlate with various age-related pathological changes including Alzheimer's disease, and cancers $[38,39]$. Enzo, et al identified that telomere length and telomerase activity in $T$ cells were the biomarkers of high-performing centenarians [2]. Consistent with previous studies, declined PBMC telomerase activity, and hTERT mRNA were observed in the older group. In the high GDF-15 tertile group, telomere length, telomerase activity, and hTERT mRNA were all significantly declined $(p<0.05)$. And elevated GDF-15 levels presented negatively correlated with decreased PBMC telomerase activity, telomere length, and WBC hTERT mRNA expression. Furthermore, the results of multivariate linear regression analysis showed GDF-15 negatively associated with telomerase length, leukocyte hTERT mRNA levels, and PBMC telomerase activity.

In the study of GDF-15 as a biomarker of aging, we also take the regulatory effect of GDF-15 on inflammation into consideration. Our study suggests circulating GDF-15 not only as a biomarker of age also distinguish person from health state.

\section{Strengths And Limitations}

Circulating GDF-15 levels displayed positively correlated with age, and statistically significant linear and negative relationship with PBMC telomerase activity, telomere length, and hTERT mRNA expression were observed. In addition, to evaluate aging by GDF-15 is more convenient, the detection of GDF-15 levels is more easier than the assays of telomere related parameters. And GDF-15 is helpful to evaluate risk factors of developing aging related diseases. This study suffers from some limitations, due to the small number of subjects in the subgroups, making it limited for us to try our power to transform our findings into a real predictor. Larger cohorts are needed to minish inter-individual difference, as well as any potential association with nutritional differences. Moreover, further work is needed to elucidate the mechanism of GDF-15 on aging, both in vitro and in vivo.

\section{Conclusion}

In male individuals with different ages, the olders has higher levels of GDF-15. And GDF-15 levels were negatively associated with telomere related parameters, after adjustment for confounders. Moreover, as an important regulator in inflammation, GDF-15 showed positive correlation with monocytes, and "bad lipids", including LDL-c and TC/HDL-C. Hence, our study suggests circulating GDF-15 levels could be used as a biomarker of age and helpful to evaluate risk fators for the development of aging related diseases. 


\section{Abbreviations}

$W B C$ white blood cell, Neu Neutrophil, $L Y M$ lymphocyte, Mono mononuclear cell, $N / L$ ratio neutrophil to lymphocyte ratio, $R B C$ red blood cell, $H b$ hemoglobin, $A L T$ alanine aminotransferase, $A S T$ aspartate aminotransferase, $A l b$ albumin, $B U N$ blood urine nitrogen, $T C$ total cholesterol, $T G$ triglyceride, $H D L-c$ high-density lipoprotein cholesterol, $L D L-c$ low-density lipoprotein cholesterol, $T / S$ ratio telomere length relative to standard reference DNA, GDF-15 growth differentiation factor-15.

\section{Tables}

Table 1 Baseline characteristics of 120 male patients stratified by age. 


\begin{tabular}{|c|c|c|c|c|}
\hline Patient characteristics & $\begin{array}{l}\text { Younger } \\
(n=53)\end{array}$ & $\begin{array}{l}\text { Middle-aged } \\
(\mathrm{n}=39)\end{array}$ & $\begin{array}{l}\text { Older } \\
(\mathrm{n}=28)\end{array}$ & $\begin{array}{l}p- \\
\text { value }\end{array}$ \\
\hline Age (years) & $27.45 \pm 4.79$ & $57.10 \pm 4.88$ & $73.14 \pm 4.97$ & $<0.001$ \\
\hline WBC $\left(\times 10^{9} / L\right)$ & $5.92 \pm 1.17$ & $5.91 \pm 1.03$ & $5.60 \pm 1.43$ & 0.494 \\
\hline $\mathrm{Neu}\left(\times 10^{9} / \mathrm{L}\right)$ & $2.98(2.37-3.51)$ & $3.15(2.69-3.40)$ & $2.60(2.27-4.48)$ & 0.596 \\
\hline $\operatorname{LYM}\left(\times 10^{9} / \mathrm{L}\right)$ & $2.23 \pm 0.59$ & $2.02 \pm 0.43$ & $1.74 \pm 0.72$ & 0.002 \\
\hline Mono $\left(x 10^{9} / \mathrm{L}\right)$ & $0.39(0.36-0.48)$ & $0.46(0.36-0.56)$ & $0.45(0.35-0.55)$ & 0.748 \\
\hline $\mathrm{N} / \mathrm{L}$ ratio & $1.31(1.02-1.58)$ & $1.40(1.19-1.75)$ & $2.12(1.13-2.63)$ & 0.056 \\
\hline $\mathrm{RBC}\left(\mathrm{x} 10^{12} / \mathrm{L}\right)$ & $5.20 \pm 0.35$ & $4.98 \pm 0.33$ & $4.62 \pm 0.44$ & $<0.001$ \\
\hline $\mathrm{Hb}(\mathrm{g} / \mathrm{L})$ & $156.71 \pm 8.99$ & $157.58 \pm 11.15$ & $147.71 \pm 10.89$ & 0.001 \\
\hline Platelets $\left(\times 10^{9} / \mathrm{L}\right)$ & $231.60 \pm 44.46$ & $220.73 \pm 50.55$ & $202.13 \pm 43.73$ & 0.049 \\
\hline $\operatorname{ALT}(\mathrm{U} / \mathrm{L})$ & $20.81 \pm 10.85$ & $19.79 \pm 8.27$ & $20.37 \pm 7.73$ & 0.877 \\
\hline AST (U/L) & $19.70 \pm 4.77$ & $21.18 \pm 5.01$ & $23.36 \pm 4.43$ & 0.012 \\
\hline Alb $(g / L)$ & $47.27 \pm 2.41$ & $44.51 \pm 2.00$ & $44.50 \pm 2.32$ & $<0.001$ \\
\hline BUN & $5.16(4.46-5.74)$ & $4.58(4.06-6.12)$ & $5.25(4.67-6.05)$ & 0.099 \\
\hline creatinine & $73.67 \pm 8.38$ & $72.54 \pm 7.07$ & $72.54 \pm 9.75$ & 0.816 \\
\hline $\mathrm{TC}(\mathrm{mmol} / \mathrm{L})$ & $4.05 \pm 0.42$ & $4.43 \pm 0.57$ & $4.42 \pm 0.63$ & 0.003 \\
\hline $\mathrm{TG}(\mathrm{mmol} / \mathrm{L})$ & $1.19(0.85-1.44)$ & $1.22(0.80-1.65)$ & $1.32(1.06-1.71)$ & 0.003 \\
\hline $\mathrm{HDL}-\mathrm{c}(\mathrm{mmol} / \mathrm{L})$ & $1.12(0.97-1.27)$ & $1.20(1.02-1.33)$ & $1.00(0.92-1.20)$ & 0.102 \\
\hline LDL-c (mmol/L) & $2.37 \pm 0.52$ & $2.57 \pm 0.54$ & $2.57 \pm 0.70$ & 0.239 \\
\hline TC to HDL-c ratio & $3.69 \pm 0.75$ & $3.88 \pm 0.66$ & $4.35 \pm 0.94$ & 0.003 \\
\hline glucose $(\mathrm{mmol} / \mathrm{L})$ & $4.50(4.33-4.70)$ & $4.48(4.34-4.67)$ & $4.95(4.51-5.58)$ & 0.001 \\
\hline $\mathrm{T} / \mathrm{S}$ ratio & $0.71 \pm 0.17$ & $0.68 \pm 0.19$ & $0.63 \pm 0.15$ & 0.191 \\
\hline hTERT $2^{-\triangle C T}$ & $\begin{array}{l}6.15 \mathrm{E}-5(3.86 \mathrm{E}- \\
5,9.56 \mathrm{E}-5)\end{array}$ & $\begin{array}{l}5.76 \mathrm{E}-5(3.82 \mathrm{E}-5,7.69 \mathrm{E}- \\
5)\end{array}$ & $\begin{array}{l}3.07 \mathrm{E}-5(1.96 \mathrm{E}-5,5.13 \mathrm{E}- \\
5)\end{array}$ & $<0.001$ \\
\hline $\begin{array}{l}\text { PBMC telomerase } \\
\text { activity }\end{array}$ & $1.20 \pm 0.55$ & $0.49 \pm 0.58$ & $0.52 \pm 0.36$ & $<0.001$ \\
\hline GDF-15 (pg/mL) & $\begin{array}{l}289.77(279.01- \\
379.32)\end{array}$ & $\begin{array}{l}477.49 \text { (392.82- } \\
724.95)\end{array}$ & $\begin{array}{l}754.18 \text { (703.84- } \\
1026.61)\end{array}$ & $<0.001$ \\
\hline
\end{tabular}

Data are presented as the mean value \pm SD or median, percent 25 -percent 75 . Differences among groups were analyzed by the one-way ANOVA and Kruskal-Wallis $\mathrm{H}$ test.

WBC, white blood cell; Neu, Neutrophil; LYM, lymphocyte; Mono, mononuclear cell; N/L ratio, neutrophil to lymphocyte ratio; RBC, red blood cell; $\mathrm{Hb}$, hemoglobin; ALT, alanine aminotransferase; AST, aspartate 
aminotransferase; Alb, albumin; BUN, blood urine nitrogen; TC, total cholesterol; TG, triglyceride; HDL-c, high-density lipoprotein cholesterol; LDL-c, low-density lipoprotein cholesterol; T/S ratio, telomere length relative to standard reference DNA; GDF-15, growth differentiation factor-15.

Table 2 Baseline characteristics of patients in the different GDF-15 (pg/mL) tertiles.

\begin{tabular}{|c|c|c|c|c|}
\hline Parameters & $\begin{array}{l}\leq 338.52 \mathrm{pg} / \mathrm{mL} \\
(\mathrm{n}=39)\end{array}$ & $\begin{array}{l}338.52-640.71 \mathrm{pg} / \mathrm{mL} \\
(\mathrm{n}=40)\end{array}$ & $\begin{array}{l}\geq 640.71 \mathrm{pg} / \mathrm{mL} \\
(\mathrm{n}=41)\end{array}$ & $p$-value \\
\hline Age (years) & $29.50(27.00-37.25)$ & $52.00(31.00-57.5)$ & $67.50(57.25-74.75)$ & $<0.001$ \\
\hline WBC $\left(\times 10^{9} / L\right)$ & $5.88 \pm 1.05$ & $5.74 \pm 1.21$ & $5.91 \pm 1.30$ & 0.796 \\
\hline Neu $\left(x 10^{9} / \mathrm{L}\right)$ & $2.99(2.30-3.84)$ & 2.78 (2.33-3.39) & $3.14(2.48-3.92)$ & 0.593 \\
\hline LYM (x109\%L) & $2.13 \pm 0.59$ & $2.09 \pm 0.46$ & $1.93 \pm 0.72$ & 0.307 \\
\hline Mono (x109/L) & $0.42(0.35-0.51)$ & $0.39(0.35-0.48)$ & $0.47(0.37-0.57)$ & 0.028 \\
\hline $\mathrm{N} / \mathrm{L}$ ratio & $1.35(1.06-1.86)$ & $1.34(1.12-1.73)$ & $1.61(1.20-2.25)$ & 0.249 \\
\hline $\mathrm{RBC}\left(\times 10^{12} / \mathrm{L}\right)$ & $5.09(4.94-5.32)$ & $5.06(4.79-5.41)$ & 4.89 (4.58-5.16) & 0.028 \\
\hline $\mathrm{Hb}(\mathrm{g} / \mathrm{L})$ & $153.83 \pm 9.22$ & $157.72 \pm 10.72$ & $152.80 \pm 11.54$ & 0.164 \\
\hline Platelets (x109/L) & $247.00(195.00-272.00)$ & $217.00(174.00-241.50)$ & $211.00(173.25-242.00)$ & 0.387 \\
\hline $\operatorname{ALT}(\mathrm{U} / \mathrm{L})$ & $15.50(10.75-21.50)$ & $21.00(16.00-29.00)$ & $19.00(14.25-23.75)$ & 0.090 \\
\hline AST (U/L) & $18.77 \pm 3.43$ & $22.28 \pm 5.44$ & $21.77 \pm 4.90$ & 0.006 \\
\hline BUN & $5.19(4.60-6.04)$ & $4.72(4.44-5.34)$ & $5.10(4.37-5.94)$ & 0.469 \\
\hline creatinine & $74.04 \pm 8.73$ & $73.14 \pm 6.91$ & $72.43 \pm 9.20$ & 0.763 \\
\hline TC (mmol/L) & $3.98(3.83-4.44)$ & $4.46(3.93-4.81)$ & $4.26(3.84-4.78)$ & 0.339 \\
\hline TG (mmol/L) & $1.21(0.85-1.45)$ & $1.26(0.88-1.67)$ & $1.24(0.92-1.60)$ & 0.175 \\
\hline HDL-c (mmol/L) & $1.10(0.99-1.32)$ & $1.20(1.01-1.31)$ & $1.01(0.95-1.21)$ & 0.302 \\
\hline LDL-c (mmol/L) & $2.36 \pm 0.51$ & $2.54 \pm 0.64$ & $2.59 \pm 0.57$ & 0.214 \\
\hline TC to HDL-c ratio & $3.73 \pm 0.70$ & $3.84 \pm 0.71$ & $4.17 \pm 0.92$ & 0.044 \\
\hline glucose (mmol/L) & $4.54(4.33-4.68)$ & $4.44(4.27-4.73)$ & $4.66(4.34-5.04)$ & 0.894 \\
\hline
\end{tabular}

Data are presented as the mean value \pm SD and median, percent 25-percent 75. Differences among groups were analyzed by the one-way ANOVA and Kruskal-Wallis $\mathrm{H}$ test.

WBC, white blood cell; Neu, Neutrophil; LYM, lymphocyte; Mono, mononuclear cell; N/L ratio, neutrophil to lymphocyte ratio; $\mathrm{RBC}$, red blood cell; $\mathrm{Hb}$, hemoglobin; $\mathrm{ALT}$, alanine aminotransferase; $\mathrm{AST}$, aspartate 
aminotransferase; Alb, albumin; BUN, blood urine nitrogen; TC, total cholesterol; TG, triglyceride; HDL-c, high-density lipoprotein cholesterol; LDL-c, low-density lipoprotein cholesterol; GDF-15, growth differentiation factor-15.

Table 3 Age-related parameters of patients in the different GDF-15 (pg/mL) tertiles.

\begin{tabular}{|c|c|c|c|c|}
\hline Parameters & $\begin{array}{l}\leq 338.52 \\
(n=39)\end{array}$ & $\begin{array}{l}338.52-640.71 \\
(n=40)\end{array}$ & $\begin{array}{l}\geq 640.71 \\
(n=41)\end{array}$ & $\begin{array}{l}p- \\
\text { value }\end{array}$ \\
\hline $\mathrm{T} / \mathrm{S}$ ratio & $0.75 \pm 0.20$ & $0.69 \pm 0.16$ & $0.60 \pm 0.11$ & $<0.001$ \\
\hline hTERT $2^{-\Delta C T}$ & $\begin{array}{l}\text { 7.72E-5 (4.39E-5, } \\
1.46 \mathrm{E}-4)\end{array}$ & $\begin{array}{l}5.10 \mathrm{E}-5 \text { ( } 2.62 \mathrm{E}-5, \\
8.00 \mathrm{E}-5)\end{array}$ & $\begin{array}{l}4.04 \mathrm{E}-5(2.12 \mathrm{E}-5 \\
6.04 \mathrm{E}-5)\end{array}$ & 0.007 \\
\hline $\begin{array}{l}\text { PBMC telomerase } \\
\text { activity }\end{array}$ & $0.97 \pm 0.59$ & $0.82 \pm 0.75$ & $0.64 \pm 0.48$ & 0.062 \\
\hline
\end{tabular}

Data are presented as the mean value \pm SD or median, percent 25-percent 75. Differences among groups were analyzed by the one-way ANOVA and Kruskal-Wallis $\mathrm{H}$ test.

T/S ratio, telomere length relative to standard reference DNA; GDF-15, growth differentiation factor-15.

Table 4 Univariate and multivariate regression analysis for GDF-15 and PBMC telomerase activity. 


\begin{tabular}{|c|c|c|c|c|c|c|c|c|}
\hline \multirow[t]{2}{*}{ Variables } & \multicolumn{4}{|c|}{ Univariate analysis } & \multicolumn{4}{|c|}{ Multivariate analysis } \\
\hline & $\begin{array}{l}\text { Unadjusted } \\
\text { coefficient }\end{array}$ & $\begin{array}{l}\text { Standardized } \\
\text { coefficient }\end{array}$ & $95 \% \mathrm{Cl}$ & $\begin{array}{l}p \\
\text { value }\end{array}$ & $\begin{array}{l}\text { Unadjusted } \\
\text { coefficient }\end{array}$ & $\begin{array}{l}\text { Standardized } \\
\text { coefficient }\end{array}$ & $\begin{array}{l}95 \% \\
\mathrm{Cl}\end{array}$ & $\begin{array}{l}p \\
\text { value }\end{array}$ \\
\hline WBC & 0.041 & 0.081 & $\begin{array}{l}-0.054 \\
\text { to } \\
0.138\end{array}$ & 0.387 & & & & \\
\hline $\mathrm{Neu}$ & 0.018 & 0.179 & $\begin{array}{l}0.000 \\
\text { to } \\
0.037\end{array}$ & 0.055 & -0.099 & -0.179 & $\begin{array}{l}-0.211 \\
\text { to } \\
0.012\end{array}$ & 0.080 \\
\hline LYM & 0.249 & 0.244 & $\begin{array}{l}0.065 \\
\text { to } \\
0.433\end{array}$ & 0.008 & & & & \\
\hline
\end{tabular}

\begin{tabular}{|c|c|c|c|}
\hline $\mathrm{N} / \mathrm{L}$ ratio & 0.004 & 0.021 & $\begin{array}{l}-0.028 \\
\text { to } \\
0.035\end{array}$ \\
\hline
\end{tabular}

\begin{tabular}{|c|c|c|c|c|c|c|c|c|}
\hline Mono & 0.342 & 0.097 & $\begin{array}{l}-0.312 \\
\text { to } \\
0.996\end{array}$ & 0.302 & & & & \\
\hline RBC & 0.475 & 0.368 & $\begin{array}{l}0.219 \\
\text { to } \\
0.732\end{array}$ & $<0.001$ & 0.191 & 0.152 & $\begin{array}{l}-0.081 \\
\text { to } \\
0.464\end{array}$ & 0.166 \\
\hline
\end{tabular}

\begin{tabular}{|c|c|c|c|c|c|c|c|c|}
\hline $\mathrm{Hb}$ & 0.007 & 0.131 & $\begin{array}{l}-0.004 \\
\text { to } \\
0.018\end{array}$ & 0.220 & & & & \\
\hline PLT & 0.003 & 0.261 & $\begin{array}{l}0.001 \\
\text { to } \\
0.006\end{array}$ & 0.013 & & & & \\
\hline ALT & 0.005 & 0.080 & $\begin{array}{l}-0.007 \\
\text { to } \\
0.017\end{array}$ & 0.392 & & & & \\
\hline AST & -0.014 & -0.111 & $\begin{array}{l}-0.037 \\
\text { to } \\
0.010\end{array}$ & 0.259 & & & & \\
\hline Alb & 0.076 & 0.335 & $\begin{array}{l}0.030 \\
\text { to } \\
0.122\end{array}$ & 0.001 & 0.051 & 0.246 & $\begin{array}{l}0.005 \\
\text { to } \\
0.097\end{array}$ & 0.030 \\
\hline
\end{tabular}

\begin{tabular}{|c|c|c|c|c|}
\hline BUN & -0.002 & -0.112 & $\begin{array}{l}-0.005 \\
\text { to } \\
0.001\end{array}$ & 0.296 \\
\hline
\end{tabular}

\begin{tabular}{|c|c|c|c|c|}
\hline creatinine & -0.005 & -0.068 & $\begin{array}{l}-0.019 \\
\text { to } \\
0.010\end{array}$ & 0.526 \\
\hline
\end{tabular}

\begin{tabular}{|c|c|c|c|}
\hline glucose & -0.201 & -0.212 & $\begin{array}{l}-0.383 \\
\text { to } \\
-0.019\end{array}$ \\
\hline
\end{tabular}

\begin{tabular}{|c|c|c|c|c|c|c|c|}
\hline TC & -0.208 & -0.194 & $\begin{array}{l}-0.415 \\
\text { to } \\
0.000\end{array}$ & 0.049 & -0.235 & -0.263 & $\begin{array}{l}-0.415 \\
\text { to } \\
-0.055\end{array}$ \\
\hline
\end{tabular}




\begin{tabular}{|c|c|c|c|c|c|c|c|c|}
\hline TG & -0.098 & -0.092 & $\begin{array}{l}-0.308 \\
\text { to } \\
0.112\end{array}$ & 0.358 & & & & \\
\hline HDL-C & -0.164 & -0.052 & $\begin{array}{l}-0.787 \\
\text { to } \\
0.460\end{array}$ & 0.604 & & & & \\
\hline LDL-C & -0.088 & -0.085 & $\begin{array}{l}-0.293 \\
\text { to } \\
0.116\end{array}$ & 0.394 & & & & \\
\hline GDF-15 & -0.371 & -0.174 & $\begin{array}{l}-0.760 \\
\text { to } \\
-0.018\end{array}$ & 0.061 & -0.583 & -0.261 & $\begin{array}{l}-1.044 \\
\text { to } \\
-0.122\end{array}$ & 0.014 \\
\hline
\end{tabular}

WBC, white blood cell; Neu, Neutrophil; LYM, lymphocyte; Mono, mononuclear cell; N/L ratio, neutrophil to lymphocyte ratio; $\mathrm{RBC}$, red blood cell; $\mathrm{Hb}$, hemoglobin; $\mathrm{ALT}$, alanine aminotransferase; $\mathrm{AST}$, aspartate aminotransferase; Alb, albumin; BUN, blood urine nitrogen; TC, total cholesterol; TG, triglyceride; HDL-c, high-density lipoprotein cholesterol; LDL-c, low-density lipoprotein cholesterol; GDF-15, growth differentiation factor-15.

Table 5 Univariate and multivariate regression analysis for GDF-15 and telomere length. 
Variables Univariate analysis

$\begin{array}{llll}\text { Unadjusted } & \text { Standardized } & 95 \% & p \\ & & \mathrm{Cl} & \text { value }\end{array}$

coefficient coefficient

WBC

$-0.018$

$-0.122$

$-0.045$

to

0.009

$\begin{array}{lllll}\text { Neu } & 0.000 & 0.007 & \begin{array}{l}-0.005 \\ \text { to }\end{array} & 0.941 \\ & & 0.006 & \\ & & & \\ \text { LYM } & -0.016 & -0.057 & \begin{array}{l}-0.070 \\ \text { to }\end{array} & 0.551 \\ & & & 0.037 & \\ & & & \end{array}$

\begin{tabular}{|c|c|c|c|}
\hline $\mathrm{N} / \mathrm{L}$ ratio & -0.005 & -0.112 & $\begin{array}{l}-0.014 \\
\text { to } \\
0.003\end{array}$ \\
\hline
\end{tabular}

Mono

$-0.141$

$-0.143$

$-0.325$

0.133

to

0.044

RBC

0.017

0.070

$-0.035$

to

0.068

$\mathrm{Hb}$

0.000

0.016

$-0.00$

to

0.002

\begin{tabular}{|c|c|c|c|c|}
\hline PLT & $-3.091 E-5$ & -0.014 & $\begin{array}{l}-0.001 \\
\text { to } \\
0.000\end{array}$ & 0.897 \\
\hline ALT & -0.002 & -0.113 & $\begin{array}{l}-0.005 \\
\text { to } \\
0.001\end{array}$ & 0.237 \\
\hline AST & -0.004 & -0.145 & $\begin{array}{l}-0.011 \\
\text { to } \\
0.002\end{array}$ & 0.145 \\
\hline Alb & 0.015 & 0.235 & $\begin{array}{l}0.002 \\
\text { to } \\
0.028\end{array}$ & 0.029 \\
\hline BUN & 0.000 & -0.041 & $\begin{array}{l}-0.001 \\
\text { to } \\
0.000\end{array}$ & 0.705 \\
\hline
\end{tabular}

creatinine $\quad 0.000$

$-0.038$

$-0.003$

0.727

to

0.002

$\begin{array}{lllll}\text { glucose } & 0.075 & 0.323 & \begin{array}{l}0.031 \\ \text { to }\end{array} & 0.001 \\ & & & 0.119 & \\ & & & & \\ \text { TC } & -0.023 & -0.071 & \begin{array}{l}-0.090 \\ \text { to }\end{array} & 0.487 \\ & & & 0.043 & \\ & & & & \end{array}$




\begin{tabular}{|c|c|c|c|c|c|c|c|c|}
\hline TG & -0.081 & -0.256 & $\begin{array}{l}-0.143 \\
\text { to } \\
-0.019\end{array}$ & 0.011 & -0.092 & -0.335 & $\begin{array}{l}-0.143 \\
\text { to } \\
-0.040\end{array}$ & 0.001 \\
\hline HDL-C & -0.225 & -0.239 & $\begin{array}{l}-0.409 \\
\text { to } \\
-0.041\end{array}$ & 0.017 & -0.206 & -0.253 & $\begin{array}{l}-0.355 \\
\text { to } \\
-0.057\end{array}$ & 0.007 \\
\hline LDL-C & -0.049 & -0.160 & $\begin{array}{l}-0.111 \\
\text { to } \\
0.012\end{array}$ & 0.114 & & & & \\
\hline GDF-15 & -0.308 & -0.517 & $\begin{array}{l}-0.404 \\
\text { to } \\
-0.212\end{array}$ & $<0.001$ & -0.200 & -0.334 & $\begin{array}{l}-0.305 \\
\text { to } \\
-0.094\end{array}$ & $<0.001$ \\
\hline
\end{tabular}

Table 6 Univariate and multivariate regression analysis for hTERT mRNA and GDF-15. 
Variables Univariate analysis Unadjusted Standardized $95 \% \mathrm{Cl}$

\begin{tabular}{|c|c|c|c|c|c|c|c|c|}
\hline & $\begin{array}{l}\text { Unadjusted } \\
\text { coefficient }\end{array}$ & $\begin{array}{l}\text { Standardized } \\
\text { coefficient }\end{array}$ & $95 \% \mathrm{Cl}$ & $\begin{array}{l}p \\
\text { value }\end{array}$ & $\begin{array}{l}\text { Unadjusted } \\
\text { coefficient }\end{array}$ & $\begin{array}{l}\text { Standardized } \\
\text { coefficient }\end{array}$ & $\begin{array}{l}95 \% \\
\mathrm{Cl}\end{array}$ & $\begin{array}{l}p \\
\text { value }\end{array}$ \\
\hline WBC & -0.027 & -0.088 & $\begin{array}{l}-0.083 \\
\text { to } \\
0.029\end{array}$ & 0.340 & & & & \\
\hline $\mathrm{Neu}$ & 0.006 & 0.091 & $\begin{array}{l}-0.006 \\
\text { to } \\
0.017\end{array}$ & 0.323 & & & & \\
\hline LYM & 0.066 & 0.108 & $\begin{array}{l}-0.045 \\
\text { to } \\
0.176\end{array}$ & 0.243 & & & & \\
\hline
\end{tabular}

\begin{tabular}{|c|c|c|c|}
\hline $\mathrm{N} / \mathrm{L}$ ratio & -0.002 & -0.023 & $\begin{array}{l}-0.021 \\
\text { to } \\
0.016\end{array}$ \\
\hline
\end{tabular}

\begin{tabular}{|c|c|c|c|}
\hline Mono & 0.043 & 0.020 & $\begin{array}{l}-0.342 \\
\text { to } \\
0.428\end{array}$ \\
\hline
\end{tabular}

\begin{tabular}{|c|c|c|c|}
\hline RBC & -0.009 & -0.011 & $\begin{array}{l}-0.191 \\
\text { to } \\
0.172\end{array}$ \\
\hline
\end{tabular}

\begin{tabular}{|c|c|c|c|}
\hline $\mathrm{Hb}$ & 0.000 & 0.011 & $\begin{array}{l}-0.007 \\
\text { to } \\
0.008\end{array}$ \\
\hline
\end{tabular}

\begin{tabular}{|c|c|c|c|c|}
\hline PLT & 0.000 & 0.052 & $\begin{array}{l}-0.001 \\
\text { to } \\
0.002\end{array}$ & 0.620 \\
\hline ALT & 0.000 & 0.013 & $\begin{array}{l}-0.007 \\
\text { to } \\
0.008\end{array}$ & 0.891 \\
\hline AST & -0.007 & -0.099 & $\begin{array}{l}-0.022 \\
\text { to } \\
0.007\end{array}$ & 0.307 \\
\hline Alb & -0.001 & -0.006 & $\begin{array}{l}-0.031 \\
\text { to } \\
0.030\end{array}$ & 0.954 \\
\hline BUN & -0.001 & -0.079 & $\begin{array}{l}-0.003 \\
\text { to } \\
0.001\end{array}$ & 0.455 \\
\hline
\end{tabular}

\begin{tabular}{|c|c|c|c|}
\hline creatinine & 0.005 & 0.119 & $\begin{array}{l}-0.004 \\
\text { to } \\
0.015\end{array}$ \\
\hline
\end{tabular}

\begin{tabular}{|c|c|c|c|c|c|c|c|c|}
\hline glucose & -0.122 & -0.215 & $\begin{array}{l}-0.230 \\
\text { to } \\
-0.015\end{array}$ & 0.026 & 0.067 & 0.287 & $\begin{array}{l}0.025 \\
\text { to } \\
0.108\end{array}$ & 0.002 \\
\hline
\end{tabular}

\begin{tabular}{|c|c|c|c|}
\hline TC & -0.077 & -0.116 & $\begin{array}{l}-0.205 \\
\text { to } \\
0.051\end{array}$ \\
\hline
\end{tabular}

Page 16/20 


\begin{tabular}{|c|c|c|c|c|c|c|c|c|}
\hline TG & -0.102 & -0.154 & $\begin{array}{l}-0.229 \\
\text { to } \\
0.026\end{array}$ & 0.116 & & & & \\
\hline HDL-C & 0.246 & 0.127 & $\begin{array}{l}-0.128 \\
\text { to } \\
0.619\end{array}$ & 0.195 & & & & \\
\hline LDL-C & -0.003 & -0.005 & $\begin{array}{l}-0.129 \\
\text { to } \\
0.123\end{array}$ & 0.960 & & & & \\
\hline GDF-15 & -0.222 & -0.175 & $\begin{array}{l}-0.448 \\
\text { to } \\
0.005\end{array}$ & 0.055 & -0.207 & -0.351 & $\begin{array}{l}-0.312 \\
\text { to } \\
-0.102\end{array}$ & $<0.001$ \\
\hline
\end{tabular}

WBC, white blood cell; Neu, Neutrophil; LYM, lymphocyte; Mono, mononuclear cell; N/L ratio, neutrophil to lymphocyte ratio; $\mathrm{RBC}$, red blood cell; $\mathrm{Hb}$, hemoglobin; ALT, alanine aminotransferase; $\mathrm{AST}$, aspartate aminotransferase; Alb, albumin; BUN, blood urine nitrogen; TC, total cholesterol; TG, triglyceride; HDL-c, high-density lipoprotein cholesterol; LDL-c, low-density lipoprotein cholesterol; GDF-15, growth differentiation factor-15.

\section{Declarations}

\section{Authors' contributions}

$\mathrm{HL}$ and $\mathrm{YH}$, carried out most of the experimental work and wrote the paper. NYL and WD collected the samples, and performed data analysis. QYT and YL directed the study. All authors read and approved the final manuscript.

\section{Author details}

${ }^{a}$ Department of Clinical Laboratory, Wuhan University, Renmin Hospital, Wuhan 430060, Hubei, China. ${ }^{b}$ Department of Clinical Laboratory, The Third Affiliated Hospital of Zhengzhou University, Zhengzhou 450000, Henan.

'Department of Cardiology, Wuhan University, Renmin Hospital, Wuhan 430060, Hubei.

\section{Acknowledgements}

We thank participants who willingly and generously provided information and samples.

\section{Competing interests}

The authors declare that they have no competing interests.

\section{Availability of data and materials}

All data generated or analysed during the study are available from the corresponding author on reasonable request.

\section{Consent for publication}

All participants provided written informed consent before enrollment in this Study.

\section{Ethics approval and consent to participate}


The research was approved by the Medical Ethics Review Committee of Wuhan University, Renmin Hospital. All of the participants were asked to provide written informed consent in accordance with Wuhan University, Renmin Hospital Ethics Committee.

\section{Funding}

This work was supported by the National Natural Science Foundation of China (Grant Numbers: 81772265).

\section{References}

1. Beard, J.R., et al., The World report on ageing and health: a policy framework for healthy ageing. Lancet, 2016. 387(10033): p. 2145-2154.

2. Tedone, E., et al., Telomere length and telomerase activity in T cells are biomarkers of high-performing centenarians. Aging Cell, 2019. 18(1): p. e12859.

3. Lv, X., et al., Folic acid delays age-related cognitive decline in senescence-accelerated mouse prone 8: alleviating telomere attrition as a potential mechanism. Aging (Albany NY), 2019. 11(22): p. 10356-10373.

4. Wang, X.B., et al., Leukocyte telomere length, mitochondrial DNA copy number, and coronary artery disease risk and severity: A two-stage case-control study of 3064 Chinese subjects. Atherosclerosis, 2019. 284: p. 165-172.

5. Bhattacharyya, J., et al., Telomere length as a potential biomarker of coronary artery disease. Indian J Med Res, 2017. 145(6): p. 730-737.

6. Huang, Y., W. Dai, and Y. Li, Potential associations of testosterone/estradiol ratio, leukocyte hTERT expression and PBMC telomerase activity with aging and the presence of coronary artery disease in men. Exp Gerontol, 2018.

7. Ait-Aissa, K., et al., Telomerase reverse transcriptase protects against angiotensin II-induced microvascular endothelial dysfunction. Am J Physiol Heart Circ Physiol, 2018. 314(5): p. H1053-H1060.

8. Bar, C., et al., Telomerase expression confers cardioprotection in the adult mouse heart after acute myocardial infarction. Nat Commun, 2014. 5: p. 5863.

9. Teo, Y.V., et al., Cell-free DNA as a biomarker of aging. Aging Cell, 2019. 18(1): p. e12890.

10. Dluzen, D.F., et al., Extracellular RNA profiles with human age. Aging Cell, 2018. 17(4): p. e12785.

11. Bootcov, M.R., et al., MIC-1, a novel macrophage inhibitory cytokine, is a divergent member of the TGF-beta superfamily. Proc Natl Acad Sci U S A, 1997. 94(21): p. 11514-9.

12. Macrophage inhibitory cytokine-1 is associated with cognitive impairment and predicts cognitive decline-the Sydney Memory and Aging Study. Aging cell, 2013.

13. Cardoso, A.L., et al., Towards frailty biomarkers: Candidates from genes and pathways regulated in aging and age-related diseases. Ageing Res Rev, 2018.

14. Wollert, K.C., T. Kempf, and L. Wallentin, Growth Differentiation Factor 15 as a Biomarker in Cardiovascular Disease. Clin Chem, 2017. 63(1): p. 140-151.

15. Cawthon, R.M., Telomere length measurement by a novel monochrome multiplex quantitative PCR method. Nucleic Acids Res, 2009. 37(3): p. e21.

16. Kim, D., C.W. Won, and Y. Park, Association between erythrocyte levels of $n-3$ polyunsaturated fatty acids and risk of frailty in community-dwelling older adults: the Korean Frailty and Aging Cohort Study. J Gerontol A Biol Sci Med Sci, 2020. 
17. Saare, M., et al., Monocytes present age-related changes in phospholipid concentration and decreased energy metabolism. Aging Cell, 2020: p. e13127.

18. Catan, A., et al., Aging and glycation promote erythrocyte phagocytosis by human endothelial cells: Potential impact in atherothrombosis under diabetic conditions. Atherosclerosis, 2019. 291: p. 87-98.

19. Yen-Chun Lai, S.P., Elena A Goncharova, TAKling GDF-15 and skeletal muscle atrophy in pulmonary hypertension: are we there yet. Thorax, 2019. 74(2): p. 103-105.

20. Arkoumani, M., et al., The clinical impact of growth differentiation factor-15 in heart disease: A 2019 update. Crit Rev Clin Lab Sci, 2019: p. 1-12.

21. Hu, X.F., et al., Growth differentiation factor 15 is associated with left atrial/left atrial appendage thrombus in patients with nonvalvular atrial fibrillation. Clin Cardiol, 2018. 41(1): p. 34-38.

22. Park H, K.C., Jeong JH, Park M, Kim KS., GDF15 contributes to radiation-induced senescence through the ROSmediated p16 pathway in human endothelial cells. Oncotarget, 2016. 7(9): p. 9634-44.

23. Hai, B., et al., Delivery of Sonic Hedgehog Gene Repressed Irradiation-induced Cellular Senescence in Salivary Glands by Promoting DNA Repair and Reducing Oxidative Stress. Theranostics, 2018. 8(4): p. 1159-1167.

24. Fuchs, T., et al., Macrophage inhibitory cytokine-1 is associated with cognitive impairment and predicts cognitive decline - the Sydney Memory and Aging Study. Aging Cell, 2013. 12(5): p. 882-9.

25. T, N., et al., Red blood cells as an organ? How deep omics characterization of the most abundant cell in the human body highlights other systemic metabolic functions beyond oxygen transport. Expert review of proteomics, 2018. 15(11): p. 855-864.

26. SB, B., H. MB, and W. CC, Accumulation of oxidized peroxiredoxin 2 in red blood cells and its prevention. Transfusion, 2015. 55(8): p. 1909-18.

27. LT, G. and S. SL, Evaluation and management of anemia in the elderly. American journal of hematology, 2014. 89(1): p. 88-96.

28. A, C., et al., Aging and glycation promote erythrocyte phagocytosis by human endothelial cells: Potential impact in atherothrombosis under diabetic conditions. Atherosclerosis, 2019. 291: p. 87-98.

29. R, P. and U.-K. M, Lymphocytes, Platelets, Erythrocytes, and Exosomes as Possible Biomarkers for Alzheimer's Disease Clinical Diagnosis. Advances in experimental medicine and biology, 2019. 1118: p. 71-82.

30. M, G., M. A, and Y. S, Developmental and Functional Heterogeneity of Monocytes. Immunity, 2018. 49(4): p. 595613.

31. KL, M., et al., Monocytes and Monocyte-Derived Antigen-Presenting Cells Have Distinct Gene Signatures in Experimental Model of Multiple Sclerosis. Frontiers in immunology, 2019. 10: p. 2779.

32. I, T. and L. AH, Monocyte-Macrophages and T Cells in Atherosclerosis. Immunity, 2017. 47(4): p. 621-634.

33. LD, S., et al., Frailty is associated with elevated CRP trajectories and higher numbers of neutrophils and monocytes. Experimental gerontology, 2019. 125: p. 110674.

34. EM, G. and Y. NS, Aging and Hematopoiesis. Clinics in geriatric medicine, 2019. 35(3): p. 285-293.

35. M, S., et al., Monocytes present age-related changes in phospholipid concentration and decreased energy metabolism. Aging cell, 2020: p. e13127.

36. Q, T., et al., Revealing a Novel Landscape of the Association Between Blood Lipid Levels and Alzheimer's Disease: A Meta-Analysis of a Case-Control Study. Frontiers in aging neuroscience, 2019. 11: p. 370.

37. M, A., et al., Age-Related Changes in the Gut Microbiota Modify Brain Lipid Composition. Frontiers in cellular and infection microbiology, 2019. 9: p. 444. 
38. Koh, S.H., et al., Telomere shortening reflecting physical aging is associated with cognitive decline and dementia conversion in mild cognitive impairment due to Alzheimer's disease. Aging (Albany NY), 2020. 12.

39. Srinivas, N., S. Rachakonda, and R. Kumar, Telomeres and Telomere Length: A General Overview. Cancers (Basel), 2020. 12(3).

\section{Figures}

Figure 1

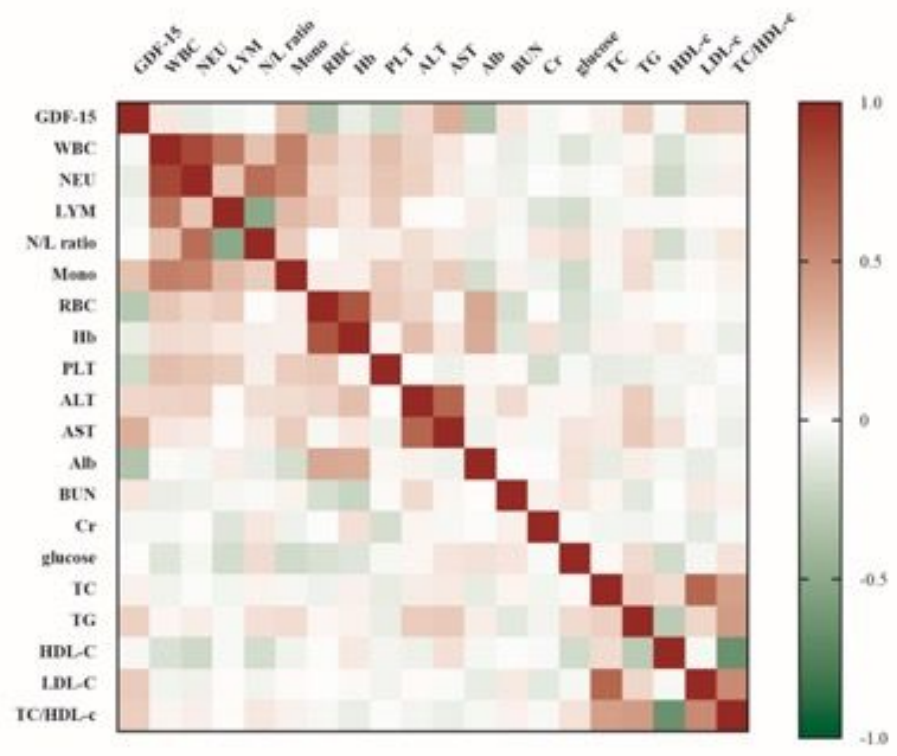

\section{Figure 1}

Correlations between GDF-15 levels and various biomarkers.

\section{Figure 2}
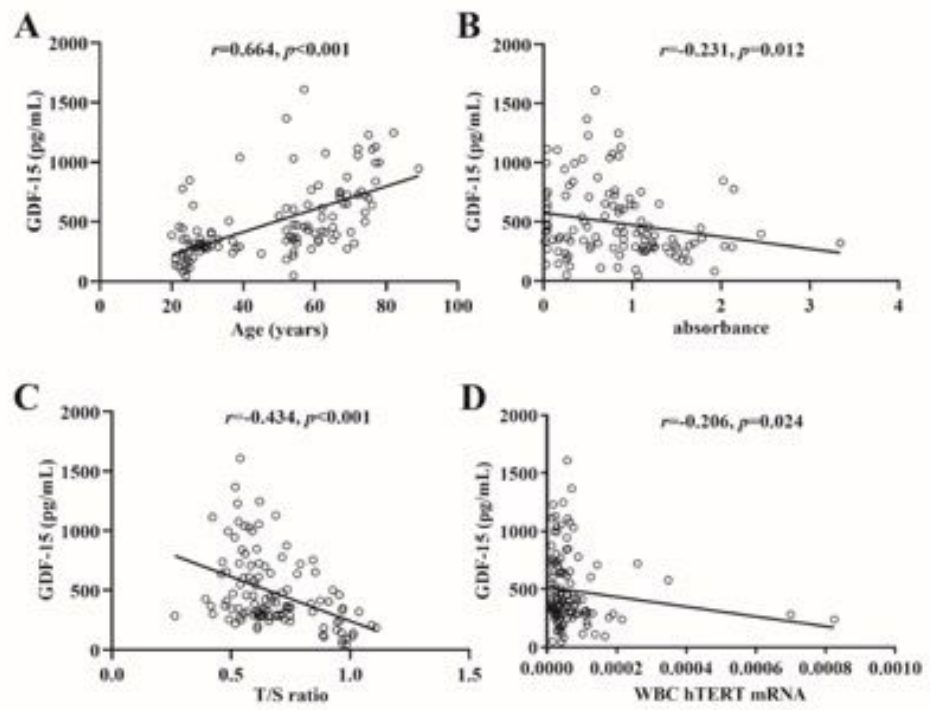

\section{Figure 2}

The correlation among GDF-15, age, T/S ratio, leukocyte hTERT mRNA levels, and PBMC telomerase activity. 